\title{
Evaluation of Patients with Iron Toxicity in Emergency Department
}

\author{
Acil Servise Demir Intoksikasyonu Olan Hastaların Değerlendirilmesi
}

\author{
Emine Emektar, Ozge 0ztekin, Seda Dagar, Huseyin Uzunosmanoglu, Yunsur Cevik \\ Department of Emergency Medicine, University of Health Sciences, Keçiören Training and Research Hospital, Ankara, Turkey
}

\begin{abstract}
Aim: In this study we aimed to analyze the demographic properties, clinical variables, treatment, complications of patients presenting to emergency department (ED) with iron toxicity.

Material and Method: This is a retrospective study. It enrolled patients presenting to the ED of a tertiary training hospital for treatment of iron toxicity. Patients with missing medical data, pregnancy, and toxicity secondary to non-iron medications were excluded. The patients were divided into 2 groups by the amount of iron. A p value of less than 0.05 was considered statistically significant.
\end{abstract}

Results: Sixty-one patients were enrolled in the study. $73.8 \%$ patients were women, and the study population had a median age of 32 (24-37) years. The mean amount of elementary iron intake was 1000 (710-1950) mg, with a fourth-hour iron level being $246 \mathrm{mg} / \mathrm{dl}$ (median, IQR 25-76:119-327). There was a significant positive correlation between the amount of iron intake and blood iron level $(p=0.02)$. Laboratory test monitoring showed a decrease in hemoglobin, platelet, and creatinine levels and an increase in INR level (for all parameters, $p<0.05$ ). No significant difference was found between the toxic and non-toxic groups with respect to any of the monitored blood parameters (for all parameters, $p>0.05$ ).

Conclusion: Iron toxicity may be encountered in clinical practice at ED. Although our results showed that about half of our patients took a toxic iron dose; the severity of toxicity was mild in a majority of them. We found a decrease in hemoglobin, platelet, and creatinine levels at laboratory but we don't believe that this finding is clinically meaningful. We detected an increase in INR level, which we believe may indicate tissue affection at cellular level without a clinical affection.

Key words: iron; intoxication; emergency

\section{ÖZET}

Amaç: Bu çalıșmada, acil kliniğine demir intoksikasyonu nedeniyle bașvuran hastaların; demografik, klinik değișkenleri, tedavileri ve komplikasyonlarını değerlendirmeyi amaçladık.

Materyal ve Metot: Bu çalıșma retrospektif bir çalıșmadır. Üçüncü basamak eğitim hastanesinin acil kliniğinde demir intoksikasyonu tanısı alan ve takip edilen hastalar çalıșmaya dâhil edildi. Verileri eksik olanlar, gebeler, demir dıșı ilaçlarla zehirlenen hastalar çalıșma dıșı bırakıldı. Hastalar demir miktarına göre iki gruba ayrıldı. $P<0,05$ istatistiksel olarak anlamlı kabul edildi.

Bulgular: Altmıș bir hasta çalıșmaya dâhil edildi. Hastaların 45'i $(\% 73,8)$ kadın olup yaș ortancası 32 (24-37) idi. Hastaların aldıkları elementer demir miktarı ortalama 1000 (710-1950) mg olup ve dördüncü saat demir düzeyleri 246 mg/dl (medyan, IQR 25-75:119327) olarak bulundu. Hastaların aldıkları demir miktarları ile kan demir düzeyi arasında istatistiksel olarak anlamlı aynı yönlü korelasyon saptandı $(p=0,02)$. Hastaların laboratuvar takiplerinde hemoglobin, platelet ve creatinin değerlerinde azalma, INR değerlerinde artma bulundu (tüm değerler için $p<0,05)$. Toksik ve nontoksik gruplar arasında takip kan parametreleri açısından fark saptanmadı (tüm değerler için $p>0,05)$.

Sonuç: Demir zehirlenmesi acil serviste klinik pratikte görülebilen zehirlenmelerdir. Çalıșma bulgularımıza göre hastalarımızın yaklașık yarısı toksik doz demir almıș olsa da büyük bir kısmında zehirlenme șiddetinin hafif olduğu görülmüștür. Hastaların laboratuvar takiplerinde hemoglobin, platelet ve creatinin değerlerinde azalma saptadık ancak klinikte anlamlı olduğunu düșünmüyoruz. Çalıșmamızda INR değerlerinde artma saptadık, bu durumun klinik etkilenme olmadan hücresel düzeyde doku etkilenmesini gösterebileceğini düșünüyoruz.

Anahtar kelimeler: demir, zehirlenme, acil servis

Iletișim/Contact: Emine Emektar, University of Health Sciences, Kecioren Training and Research Hospital, Department of Emergency Medicine, Ankara, Turkey • Tel: 05055562675 • E-mail: emineakinci@yahoo.com • Geliș/Received: 01.04.2020 • Kabul/Accepted: 12.07 .2020

ORCID: Emine Emektar, 0000-0002-6056-4401 • Özge Öztekin, 0000-0002-2469-9819 • Seda Dağar, 0000-0002-7874-382X • Hüseyin Uzunosmanoğlu, 0000-0002-4370-1283 • Yunsur Çevik, 0000-0003-1325-0909 


\section{Introduction}

Toxicity, a condition that kills an organism after the entry of toxic materials into the body, is the emergence of certain signs and symptoms after the intake of the culprit substance at an amount sufficient to harm the body. Being responsible for an important proportion of emergency department (ED) admissions, toxicity occurs by intake of medications or other substances via oral route, inhalation, or injection, either inadvertently or for suicidal aim ${ }^{1}$. Depending on the route of intake, a multidisciplinary approach may be required. Acute iron toxicity most commonly occurs by accidental intake among children younger than 5 years. In the United States approximately 11.000 cases of iron toxicity are reported annually among children younger than 6 years of age $^{2}$. The total number of exposures in this age group has dropped in recent years. Additionally, the incidence of serious complications and death among children has now improved compared to 1990 $\mathrm{s}$ and $2000 \mathrm{~s}$. However, death due to both inadvertent and deliberate iron intake still occurs ${ }^{2}$. Iron preparations are combined with many other minerals and vitamins, which increases the incidence of iron toxicity ${ }^{3}$. It may occur by suicidal purpose or by overdose of vitamins containing iron. An excessive amount of iron taken via oral route affects the gastrointestinal barrier by its direct caustic effect on the gastrointestinal system mucosa, which leads to massive iron absorption. Iron toxicity mainly affects liver, but the heart, kidneys, lungs, and the hematological system are also affected $^{4-6}$. Severity of toxicity depends on the amount of iron. The risk of toxicity is lower below a dose of 20 $\mathrm{mg} / \mathrm{kg}$, and decontamination and monitoring for at least 6 hours are recommended for such cases. There is a moderate risk of toxicity at doses of $20-40 \mathrm{mg} / \mathrm{kg}$, where decontamination should be performed and chelation should be considered. Doses above $60 \mathrm{mg} / \mathrm{kg}$ are high-risk, where chelation therapy should be started in addition to decontamination ${ }^{7}$. Excess iron intake may progress from acute liver necrosis to multi organ failure syndrome and is potentially fatal ${ }^{8-10}$.

In the present study we aimed to evaluate the demographic, clinical, and laboratory features, treatment modalities, and complications of patients presenting to our ED with iron toxicity.

\section{Materials and Method}

This study is a retrospective study. It enrolled patients aged 18 years or older seen at the emergency department of Keçiören Health Training and Research Center Hospital between 01.01.2013 and 31.05.2019, who had been recorded with the ICD code of X60 (Intentional self-poisoning by and exposure to nonopioid analgesics, antipyretics, and anti rheumatics) and diagnosed with iron toxicity on the basis of information obtained from hospital system and medical records. Patients with missing medical data, pregnancy, or toxicity with a non-iron medication were excluded. We recorded the demographic information, vital signs, amount of iron, intake of any other additional medication, blood iron level, hospital outcome, and the results of full blood count and serum biochemistry tests obtained at admission and during hospital stay. The patients were divided into 2 groups by the amount of iron. In the case of acute iron intake, doses below $20 \mathrm{mg} / \mathrm{kg}$ were considered as non-toxic while those above $21 \mathrm{mg} / \mathrm{kg}$ were considered toxic. In our clinic deferoxamine is administered via intravenous route for iron toxicity as per iron toxicity protocols.

\section{Statistical Analysis}

The statistical analyses of the study data were performed with IBM SPSS 20.0 software package. The normality of distribution of discrete and continuous numeric variables was tested with Kolmogorov Smirnov test. The descriptive statistics included median (minimummaximum) for discrete and continuous variables and the number of observations and percentage (\%) for categorical variables. Categorical variables were compared using Chi-square test and continuous variables using Man Whitney U and Wilcoxon test. Any correlation between the amount of iron intake and blood iron level was tested using Spearman's correlation test. A p value of less than 0.05 was considered statistically significant.

\section{Results}

The medical records of a total of 753 patients were reviewed. Sixty-five patients were found to present with iron intoxication. Four patients were excluded due to missing medical information, and a final number of 61 patients were included in the statistical analyses.

Forty-five (73.8\%) patients were female, and the median age of the study population was 32 (24-37) years. About half of the patients had taken an additional medication other than iron, with the most common 
group being analgesics (all drug was NSAID). The mean amount of elementary iron taken was 1000 (710-1950) $\mathrm{mg}$, and the fourth-hour iron level was $246 \mathrm{mg} / \mathrm{dl}$ (median, IQR 25-75:119-327). None of the patients died. The demographic information of the study population was given on Table 1 .

There was a weak but statistically significant positive correlation between the amount of iron intake and blood iron level ( $\mathrm{r}=0.388$ and $\mathrm{p}=0.02)$ (Table 2).

A comparison of the blood parameters at admission and during follow-up showed a significant decrease in hemoglobin, platelet, WBC, and creatinine levels $(\mathrm{p}<0.001, \mathrm{p}=0.005, \mathrm{p}=0.001$, respectively). There occurred a significant increase in the INR level during follow-up compared to admission level $(p=0.014)$ (Table 3). No significant difference was seen in other blood parameters.

No significant difference was found between the toxic and non-toxic groups with respect to blood parameters obtained at follow-up (for all parameters $\mathrm{p}>0.05$ ) (Table 4).

Table 1. Demographic information of the study population

\begin{tabular}{ll}
\hline $\begin{array}{l}\text { Sex } \mathrm{n}(\%) \\
\text { Female }\end{array}$ & $45(73.8 \%)$ \\
\hline Age median (IQR 25-75) & $32(24-37.5)$ \\
\hline Intake of additional medication, $\mathrm{n}(\%)$ & $30(49.2 \%)$ \\
\hline Additional medications taken, $\mathrm{n}(\%)$ & $13(43.3 \%)$ \\
$\quad$ Analgesics & $3(10 \%)$ \\
Antibiotics & $3(10 \%)$ \\
Acetyl salicylic acid & $11(36.7 \%)$ \\
Other & $21(34.4 \%)$ \\
\hline Gastric lavage administered, $\mathrm{n}(\%)$ & $30(49.2 \%)$ \\
\hline Activated charcoal administered, $\mathrm{n}(\%)$ & $1000(710-1950)$ \\
\hline Amount of iron gr median (IQR 25-75) & $28(45.9 \%)$ \\
\hline Number of patients taking a non-toxic dose, $\mathrm{n}(\%)$ & $33(55.1 \%)$ \\
Number of patients taking a toxic dose, $\mathrm{n}(\%)$ & $246(119-327.5)$ \\
\hline 4. hour iron level median $\mu \mathrm{g} / \mathrm{dl}(\mathrm{IQR} 25-75)$ & \\
\hline Vital signs median (IQR 25-75) & $113(107-124)$ \\
Systolic blood pressure mm/Hg & $70(64-75.5)$ \\
Diastolic blood pressure mm/Hg & $84(79-97)$ \\
\hline Pulse rate/minute & $7(11 \%)$ \\
\hline Antidote administered, $\mathrm{n}(\%)$ & $54(88.5 \%)$ \\
\hline Patient outcome, $\mathrm{n}(\%)$ & $5(8.2 \%)$ \\
Discharge & $2(3.3 \%)$ \\
Admission to regular ward & \\
Admission to intensive care unit & \\
\hline
\end{tabular}

IQR, inter quartile range.

\section{Discussion}

In the present study we studied the demographic information, treatment modalities, and complications of the patients presenting to the ED with iron toxicity, and we reached two findings. Firstly, although about half of our patients had taken a toxic dose of iron, there was a weak correlation between the amount of iron intake and blood iron level. Secondly, we detected a decrease in hemoglobin, white blood cell, platelet, and

Table 2. Correlation between the amount of iron intake and blood iron level

\begin{tabular}{lcc}
\hline Amount of iron intake & $r$ & $p$ \\
\hline Blood iron level & 0.388 & 0.002 \\
\hline
\end{tabular}

Table 3. Comparison of laboratory levels at admission and during followup

\begin{tabular}{lccc}
\hline Median IQR (25-75) & Admission level & Follow-up level & $\mathrm{p}$ \\
\hline Hemoglobin & $13.6(12.4-15.3)$ & $12.1(10.8-13.3)$ & $<0.001$ \\
WBC & $9.6(8.9-10.3)$ & $8.9(6.99-10.3)$ & 0.014 \\
Platelet & $267(206-318.5)$ & $261(214-287)$ & 0.005 \\
Glucose & $128(130-157)$ & $122(118-134)$ & 0.067 \\
Creatinine & $0.73(0.67-0.80)$ & $0.68(0.6-0.77)$ & 0.001 \\
Bicarbonate & $24.6(22.8-26.4)$ & $23.5(22.2-26)$ & 0.084 \\
Lactate & $1.6(1.02-2)$ & $1.4(1-2.1)$ & 0.695 \\
AST & $20(17-25)$ & $16(14-20)$ & 0.102 \\
ALT & $14(10-20)$ & $11.5(10-15.7)$ & 0.071 \\
INR & $1.09(1.02-1.16)$ & $1.24(1.20-1.25)$ & 0.014 \\
\hline ALT, alanine amino transferase; AST, aspartate transaminase; INR, international normalized ratio; \\
IQR, inter quartile range.
\end{tabular}

Table 4. Comparison of laboratory parameters between toxic iron dose and non-toxic iron dose groups

\begin{tabular}{lccc}
\hline Median IQR (25-75) & Non-toxic group & Toxic group & $\mathrm{p}$ \\
\hline Hemoglobin & $11.9(11-13.8)$ & $12.4(10.2-13.4)$ & 0.867 \\
WBC & $9.03(6.76-10.75)$ & $8.8(7.1-10.25)$ & 0.841 \\
Platelet & $287(240-314.5)$ & $226(198-278)$ & 0.057 \\
Glucose & $121(127-148)$ & $125(112-137)$ & 0.566 \\
Creatinine & $0.68(0.65-0.80)$ & $0.66(0.59-0.75)$ & 0.445 \\
Bicarbonate & $24.5(23.3-26)$ & $22.7(21.8-25.8)$ & 0.163 \\
Lactate & $1.26(0.9-1.6)$ & $1.6(1-2.7)$ & 0.695 \\
AST & $15(17-25)$ & $16(14-20)$ & 0.977 \\
ALT & $14(13-33)$ & $16(14-20)$ & 0.537 \\
INR & $1.24(1.21-1.25)$ & $1.24(1.20-1.25)$ & 0.606 \\
\hline
\end{tabular}

ALT, alanine amino transferase; AST, aspartate transaminase; INR, international normalized ratio; IQR, inter quartile range. 
creatinine levels and an increase in INR level. We did not find any difference in renal and hepatic function tests at follow-up in the toxic or non-toxic groups.

Iron is an essential element for normal cellular metabolism. However, when taken in large amounts, it may affect almost all organs, and it may be cytotoxic or even fatal ${ }^{4,5}$. Clinical outcomes vary by the amount of absorbed iron and the delay in treatment. The major causes of iron toxicity in adults are suicide attempts and excess iron intake during pregnancy ${ }^{11}$. A review of our patients' medical records indicated that approximately half of them had taken toxic doses of iron. However, there was a weak correlation between the amount of iron intake and the fourth-hour iron level. This may be due totally of our patients having taken iron for suicidal purpose and, given the psychologically problematic process they had been through, medical history obtained from them may have lost its reliability. Iron sulphate is the most commonly used oral iron preparation and contains $20 \%$ elementary iron. High-dose iron may cause multi-organ failure and hepatic necrosis ${ }^{4-6}$. The clinical effects of acute iron toxicity can be examined in five stages. The first stage is characterized by gastrointestinal toxicity that emerges within the first 6 hours of intake. The symptoms include abdominal pain, vomiting, diarrhea, and gastrointestinal bleeding. These symptoms occur as a result of fluid translocation into the gastrointestinal system lumen induced by an elevated serum iron level as well as direct mucosal injury brought about by iron binding to the mucosa. The second stage is the stabilization stage that occurs between the $12^{\text {th }}$ and $24^{\text {th }}$ hours of intake. A transient and misleading recovery is seen in this stage. Hypotension may develop due to metabolic acidosis and increased capillary permeability. The third stage is the mitochondrial toxicity stage that develops between the $24^{\text {th }}$ and $48^{\text {th }}$ hours after iron intake. It is characterized by signs of shock, acidosis, coagulopathy, hyperglycemia, and acute tubular necrosis. The fourth stage is the hepatotoxicity stage and occurs by 48 hours after intake. The fifth stage is the gastric scarring stage which may occur as a late complication 2-4 weeks after intake ${ }^{6}$. Metabolic acidosis and acute renal or hepatic failure may develop in severe iron toxicity. The amount of iron intake and blood iron level may not correlate. There is a number of studies in the literature that have examined the relationship between laboratories tests taken at admission and severity of toxicity among patients presenting to emergency department with iron toxicity ${ }^{12-14}$. They have suggested that a high anion gap metabolic acidosis is an important but nonspecific predictor of iron toxicity. Several studies have shown that leukocytosis (white blood cell count $>15.000$ cells $/ \mathrm{mi}$ croL) and hyperglycemia ( $>150 \mathrm{mg} / \mathrm{dL})$ are correlated with serum iron levels above $300 \mathrm{mcg} / \mathrm{dL}^{13}$.

Unlike literature data, we found a decrease in hemoglobin, white blood cell, platelet, and creatinine levels during patients' stay in the ED. We believe that this may have occurred due to hydration of the patients at the ED. On the other hand, we detected an increased INR level. When serum iron level exceeds the body's binding capacity, free radicals are formed and cell lysis occurs as a result of lipid peroxidation ${ }^{15}$. We believe that this may indicate tissue affection at cellular level without necessarily clinical hepatic affection. We formed the toxic group of patients according to the amount of iron intake which was learned from the patient history. However, the majority of patients in the toxic group did not develop any serious clinical sign or symptom during their follow-up. Only seven patients were administered chelation treatment in the form of deferoxamine. None of our patients developed hepatotoxicity, metabolic acidosis, or acute renal failure. Moreover, we did not detect any significant difference between the toxic and non-toxic groups with regard to follow-up renal or hepatic tests. There are an insufficient number of publications on iron toxicity in adults.

In conclusion, we are of the opinion that the absence of leukocytosis, hyperglycemia, or an increase in any other parameter cannot be used to rule out iron toxicity. There is a need for further studies in this field.

\section{Limitations}

First of all, our study was a retrospective one in which our patients' data were accessed via their medical records. Another limitation is the lack of determination of time from iron intake to hospital admission.

\section{Conclusion}

Iron toxicity is encountered in clinical practice at Ed. According to our study results, although about half of our patients had taken a toxic dose of iron, toxicity was mild in a majority of them. We showed a decrease in hemoglobin, platelet, and creatinine levels at laboratory follow-up but we do not consider it a clinically meaningful finding. We also found an increase in INR level, which we believe may indicate tissue affection at cellular level without any clinical affection. 


\section{Funding}

This research received no specific grant from any funding agency in the public, commercial, or not-for-profit sectors.

\section{Conflict of Interest}

The authors declare that there is no conflict of interest.

\section{Human Rights}

The study protocol conforms to the ethical guidelines of the 1975 Declaration of Helsinki.

\section{Author Contribution}

Analysed data, writing original draft preparation and co-writing the paper: Emine Emektar, Seda Dagar; Review and editing original draft and Supervised the research: Huseyin Uzunosmanoglu, Yunsur Cevik; Data collecting; Ozge Oztekin

\section{References}

1. Günaydın YK, Akıllı NB, Dündar ZD, Köylü R, Sert ET, Çekmen B, Akıncı E, Cander B. Toxicol Rep 2014;18(2):5662. eCollection 2015. Antiepileptic drug poisoning: Three-year experience.

2. Gummin DD, Mowry JB, Spyker DA, et al 2017 Annual Report of the American Association of Poison Control Centers' National Poison Data System (NPDS): 35th Annual Report. Clin Toxicol (Phila) 2018;56:1213.
3. Anderson BD, Turchen SG, Manoguerra AS, Clark RF. Retrospective analysis of ingestions of iron containing products in the united states: are there differences between chewable vitamins and adult preparations? J Emerg Med 2000;19:255.

4. Proudfoot AT, Simpson D, Dyson EH. Management of Acute Iron Poisoning. Med Toxicol 1986;1:83-100.

5. Skoczynska A, Kwiecinska D, Kielbinski M, Lukaszewski M. Acute Iron Poisoning in Adult Female. Hum Exp Toxicol2007;26:663-666.

6. Tenenbein M. Hepatotoxicity in Acute Iron Poisoning.J Toxicol Clin Toxicol 2001;39:721-726.

7. Baranwal AK, Singhi SC. Acute Iron Poisoning: Management Guidelines. Indian Pediatr2003;40:534-540.

8. Robertson A, Tenenbein M. Hepatotoxicity in acute iron poisoning. Hum Exp Toxicol 2005;24:559-562.

9. Morse SB, Hardwick WE Jr, King WD. Fatal iron toxicity in an infant. South Med J 1997;90:1043.

10. Audimoplam VK, Wendon J, Bernal W, Heaton N, O'Grady J, Auzinger G. Iron and Acetaminophen a Fatal Combination? Transpl Int 2011;24:85-88.

11. Skoczynska A1, Kwiecinska D, Kielbinski M, Lukaszewski M. Acute iron poisoning in adult female. Hum Exp Toxicol 2007;26(8):663-666.

12. Palatnick W, Tenenbein M. Leukocytosis, hyperglycemia, vomiting, and positive $\mathrm{X}$-rays are not indicators of severity of iron overdose in adults. Am J Emerg Med 1996;14:454.

13. Lacouture PG, Wason S, Temple AR, et al. Emergency assessment of severity in iron overdose by clinical and laboratory methods. J Pediatr 1981;99:89.

14. Black J, Zenel JA. Child abuse by intentional iron poisoning presenting as shock and persistent acidosis. Pediatrics 2003;111:197.

15. Tenenbein M, Israels SJ. Early coagulopathy in severe iron poisoning. J Pediatr 1988;113:695. 